\title{
GEOLOGI DAN MINERALISASI DAERAH SATOKO KABUPATEN POLEWALI MANDAR, SULAWESI BARAT
}

\author{
Oleh: \\ Ernowo, Bambang Nugroho Widhi, Moe'tamar \\ Pusat Sumber Daya Geologi \\ JI. Soekarno-Hatta No. 444 Bandung
}

\section{SARI}

Batuan pembawa mineralisasi daerah Satoko berupa syenodiorit yang telah mengalami ubahan argilik dengan komposisi didominasi monmorilonit dan haloisit dengan sedikit nontronit. Luas daerah mineralisasi sekitar $0.49 \mathrm{~km}^{2}$, dalam bentuk urat-urat kuarsa yang teramati pada beberapa sumur uji. Urat kuarsa berwarna putih susu dengan struktur banded, vuggy dan dog teeth terisi pirit sangat halus, oksida besi, hematit dan limonit. Ketebalan urat kuarsa bervariasi antara $2-4 \mathrm{~cm}$ dan membentuk zona urat mencapai lebar $40 \mathrm{~cm}$. Analisis kimia dari conto urat kuarsa menunjukkan nilai tertinggi kandungan unsur logam 6.326 ppm Au, 40 ppm Cu, 5.526 ppm Pb, 379 ppm Zn, 5 ppm Ag, 4.65\% Fe, 35 ppm As, 8 ppm Mo dan 7 ppm Sb.

Korelasi yang erat ditunjukkan oleh kemunculan $\mathrm{Cu}, \mathrm{Pb}$ dan $\mathrm{Zn}$ dengan nilai koefisien diatas 0,8, sedangkan Au menunjukkan korelasi negatif dengan unsur-unsur lain. Analisis inklusi fluida mengindikasikan mineralisasi terjadi pada kisaran temperatur antara $220^{\circ}-300^{\circ} \mathrm{C}$ dan kedalaman 291,53 - 863,16 m. Kisaran temperatur tersebut merupakan lingkungan tipe mineralisasi epitermal.

Kata kunci : mineralisasi, inklusi fluida, epitermal

\begin{abstract}
The host rock of Satoko mineralization area is argillic altered syenodiorite dominated by montmorilonite, haloysite and slightly nontronite. The mineralization zone covers an area of about $0.49 \mathrm{~km}^{2}$, as quartz veins observed in some test pits. Milky white quartz veins have structures of banded, vuggy and dog teeth and filled by very fine pyrite, iron oxide, hematite and limonite. The thickness of quartz vein varies between $2-4 \mathrm{~cm}$ and form a vein zone up to $40 \mathrm{~cm}$ wide. Chemical analysis (AAS) from a quartz vein samples showed the highest content of some metals named 6.326 ppm Au, 40 ppm Cu, 5.526 ppm Pb, 379 ppm Zn, 5 ppm Ag, 4.65\% Fe, 35 ppm As, 8 ppm Mo and 7 ppm Sb.
\end{abstract}

A close correlation of $\mathrm{Cu}, \mathrm{Pb}, \mathrm{Zn}$ represented by coefisien value of above 0.8 , but none for $\mathrm{Au}$. Fluid inclusions analysis indicates that the temperature of mineralization formed at $220^{\circ}-300^{\circ} \mathrm{C}$ and depth of 291,53 - 863,16 $\mathrm{m}$. The temperature range is the typical of epithermal mineralization environment.

Keywords : mineralization, fluid inclusion, epithermal 


\section{PENDAHULUAN}

Daerah penelitian terletak di bagian tengah wilayah Kabupaten Polewali Mandar, secara geografis berada pada koordinat $119^{\circ} 6^{\prime} 32,39^{\prime \prime}$ - 119 $8^{\prime} 27,18^{\prime \prime}$ Bujur Timur dan $3^{\circ} 17^{\prime} 56,15^{\prime \prime}$ sampai $3^{\circ} 18^{\prime} 54,08^{\prime \prime}$ Lintang Selatan (Gambar 1). Penelitian ini dilakukan untuk mengetahui keadaan geologi dan mineralisasi daerah Satoko dengan tujuan untuk mengetahui lingkungan pembentukan mineral emas.

Beberapa kegiatan penelitian untuk pencarian mineral telah banyak dilakukan di Kabupaten Polewali Mandar diantaranya oleh PT. Altar Makale Mining (1987 - 1989) melaksanakan penyelidikan mineral logam di wilayah Polewali dan Toraja, PT. Kalosi Minerals (1987-1994) yang melakukan eksplorasi cebakan sulfida masif (massive sulphide) dan yang terkait dengan mineralisasi emas di Satoko dilakukan oleh PT. North Mining Toraja dari tahun 1997 sampai tahun 2001 dengan hasil ditemukannya mineralisasi tipe epitermal pada batuan syenodiorit.

Dalam penelitian ini dilakukan penyelidikan lapangan untuk pemetaan geologi dan mengidentifikasi indikasi mineralisasi. Sebanyak 34 conto batuan terubah dan batuan termineralisasi diambil pada parit uji serta sumur uji untuk dilakukan analisis laboratorium yang meliputi :

- 25 conto untuk analisis Atomic Absorption Spectometry (AAS) guna mengetahui kandungan unsur $\mathrm{Cu}, \mathrm{Pb}, \mathrm{Zn}$, $\mathrm{Fe}, \mathrm{Au}, \mathrm{Ag}, \mathrm{As}, \mathrm{Sb}, \mathrm{Mo}$.

- 6 conto dilakukan analisis Portable Infrared Mineral Analyzer (PIMA) untuk mengetahui jenis mineral-mineral ubahan.

- 3 conto untuk analisis inklusi fluida guna mengetahui suhu dan kedalaman pembentukan kuarsa dan cebakan bijih.

\section{GEOLOGI}

Kabupaten Polewali Mandar merupakan bagian dari mandala geologi Sulawesi Barat Bagian Tengah berada pada busur magmatik barat di ujung timur Paparan Sunda.(Van Leeuwen \& Pieters, 2011) (Gambar 2).

Mandala Sulawesi Barat Bagian Tengah merupakan daerah yang memiliki topografi paling terjal, terdiri dari beberapa punggungan dengan ketinggian antara $2.000-3.495 \mathrm{~m}$ diatas permukaan air laut.

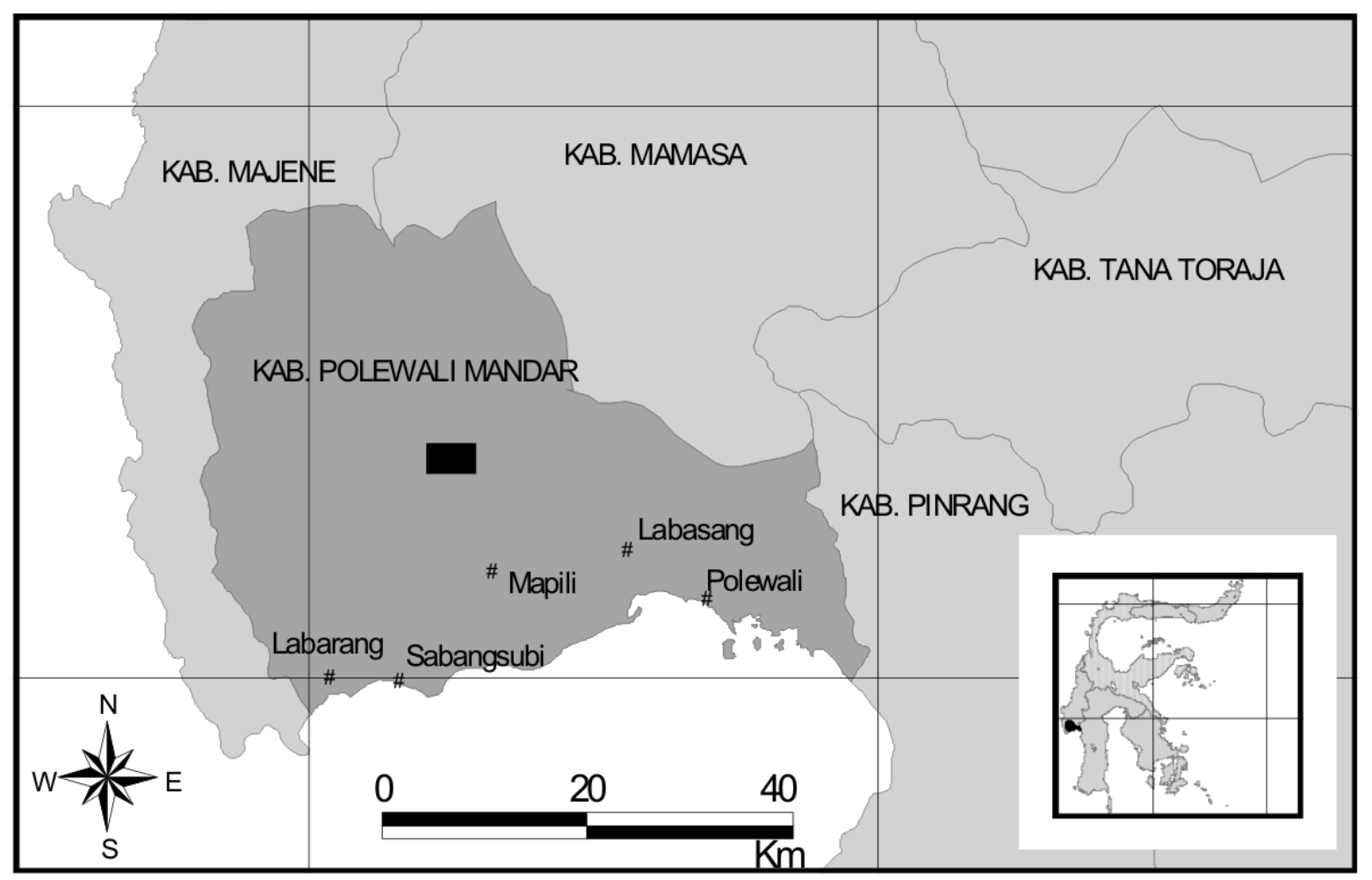

Gambar 1. Peta Lokasi daerah penelitian 


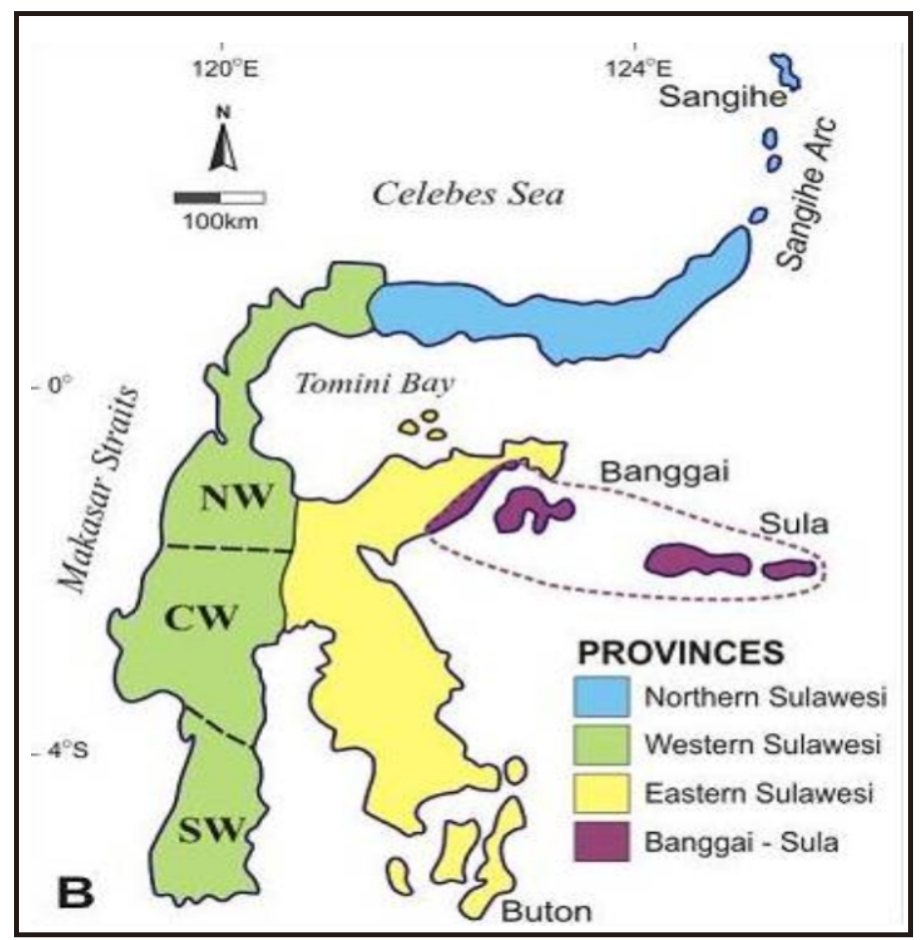

Gambar 2. Mandala metalogen Sulawesi (Van Leeuwen \& Pieters, 2011).

Geologi Sulawesi Barat memiliki uruturutan stratigrafi dengan kisaran umur mulai Kapur Akhir sampai sekarang, yang tersusun oleh fragmen benua dan batuan akresi (mélange). Kompleks batuan dasar secara tidak selaras ditumpangi oleh endapan flysch termetamorfosakan derajat rendah yang berumur Kapur Akhir dan tersebar luas serta membawa mineralisasi emas di Sulawesi Barat Bagian Tengah.

Geologi regional Polewali Mandar tersusun oleh Formasi Makale, Formasi Latimojong, Formasi Sekala, Batuan Gunungapi Gunung Walimbong, Batuan Terobosan dan Endapan Alluvial (Djuri dkk, 1998).

Formasi Latimojong berumur Kapur mengalami metamorfisme lemah - sedang terdiri dari serpih, filit, rijang, marmer, kuarsit dan breksi terkersikkan. Secara tidak selaras di atas Formasi Latimojong diendapkan Formasi Makale berumur Miosen Awal Miosen Tengah berupa batugamping terumbu.

Formasi Sekala berumur Mio-Pliosen yang disusun oleh batupasir, konglomerat, serpih, tuf, sisipan lava andesitan - basalan berumur Miosen Tengah - Pliosen memiliki hubungan menjari dengan Batuan Gunungapi Walimbong berumur Miosen Pliosen terdiri dari lava bersusunan basal sampai andesitan, sebagian lava bantal; breksi andesit piroksin, breksi andesit trakit; mengandung feldspatoid di beberapa tempat. Batuan Gunungapi Walimbong diterobos oleh Batuan Terobosan yang pada umumnya berkomposisi asam sampai menengah berumur Pliosen.

Endapan alluvium berumur Kuarter berupa lempung, lanau, pasir, dan kerikil menutupi dataran rendah di bagian selatan Kabupaten Polewali Mandar.

Litostratigrafi daerah Satoko disusun oleh satuan batupasir yang merupakan bagian dari Formasi Sekala berumur MioPliosen dan Satuan Tufa dengan intrusi syenodiorit yang merupakan anggota dari Formasi Gunungapi Walimbong berumur Miosen (Gambar 3).

Struktur yang berkembang adalah sesar mendatar dan normal dengan arah tenggara - barat laut memotong kedua satuan batuan yang merupakan jalur keluarnya larutan hidrotermal pembawa larutan sisa magma. Batuan terobosan syenodiorit kemungkinan merupakan 


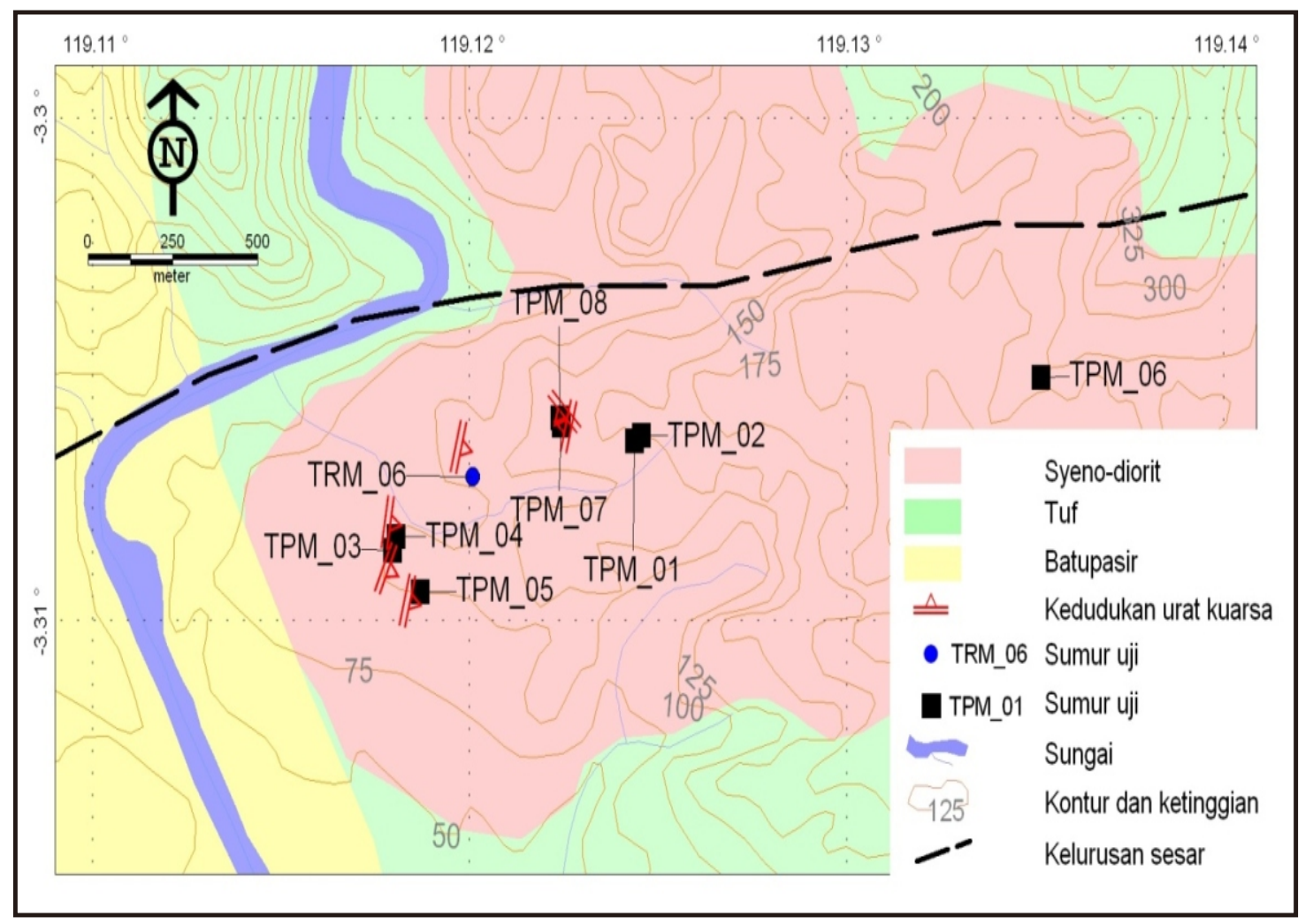

Gambar 3. Peta Geologi daerah Satoko, Polewali Mandar

Tabel 1.

Kandungan mineral ubahan hasil analisis PIMA

\begin{tabular}{|c|c|}
\hline No. Conto & Susunan mineral ubahan \\
\hline TPM_01B & $52 \%$ montmorilonit $+48 \%$ haloisit \\
\hline TPM_03C & $46 \%$ montmorilonit $+54 \%$ haloisit \\
\hline TPM_05A & $47 \%$ montmorilonit $+53 \%$ haloisit \\
\hline TPM_06A & $50 \%$ montmorilonit $+50 \%$ haloisit \\
\hline TPM_07 & $50 \%$ montmorilonit $+50 \%$ haloisit \\
\hline TRM_06A & $69 \%$ montmorilonit $+31 \%$ nontronit \\
\hline
\end{tabular}

bagian dari satuan batuan terobosan Granit Mamasa. Priadi dkk. (1994) melakukan penentuan umur dengan metode 40K-40Ar

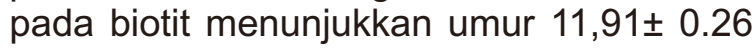
Ma (Miosen Tengah).

\section{ALTERASI DAN MINERALISASI}

Batuan syenodiorit merupakan batuan induk yang seluruhnya telah mengalami ubahan argilik, sehingga tidak diketemukan conto batuan yang segar. Hal tersebut ditunjukkan dari hasil analisis PIMA dengan munculnya mineral-mineral ubahan yang didominasi oleh monmorilonit, halosit dan sedikit nontronit (Tabel 1, Gambar 4), pada beberapa tempat dijumpai juga klorit.

Zona mineralisasi Satoko meliputi area seluas $\pm 0,49 \mathrm{~km} 2$. Mineralisasi teramati pada beberapa sumur uji dalam bentuk uraturat kuarsa (Gambar 5). Urat kuarsa berwarna putih susu, memiliki struktur banded, vuggy dan dog teeth yang pada 


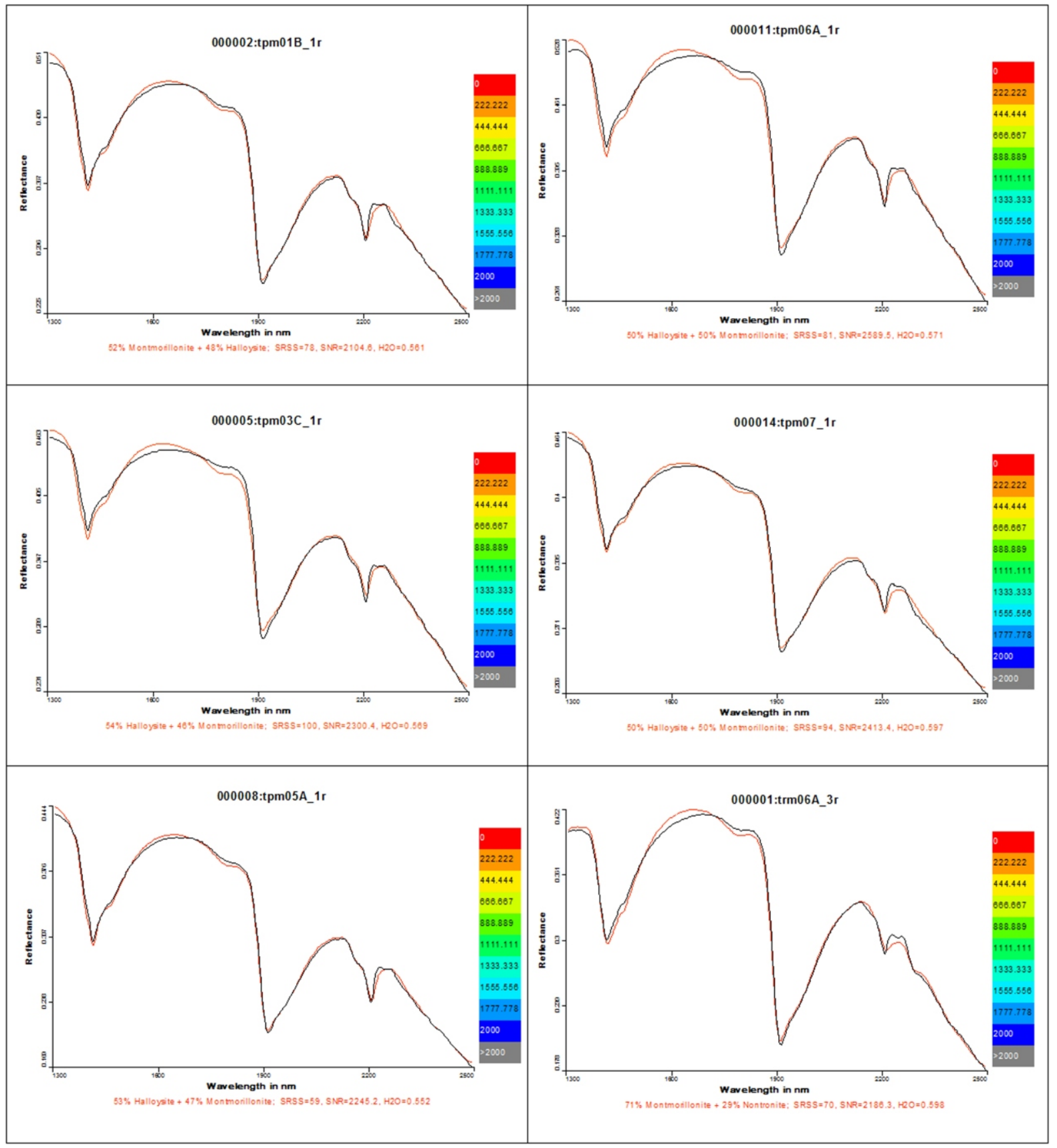

Gambar 4. Diagram analisis PIMA

beberapa bagian terisi pirit sangat halus, oksida besi, hematit dan limonit pada rongga-rongganya. Urat sudah mengalami retak-retak karena sifat getas (brittle) dan mengalami pelapukan dengan ketebalan bervariasi antara 2 - $4 \mathrm{~cm}$ dan membentuk zona urat mencapai lebar $40 \mathrm{~cm}$.

Analisis kimia metode AAS dari beberapa conto urat kuarsa yang diambil dari sumur uji menunjukkan kandungan tertinggi dari beberapa unsur logam yaitu 6,326 ppm Au, 40 ppm Cu, 5.526 ppm Pb, 379 ppm Zn, 5 ppm Ag, 4,65\% Fe, 35 ppm As, 8 ppm Mo dan 7 ppm Sb. (Tabel 2).

Analisis inklusi fluida terhadap conto TPM_04A, TPM_5D dan TPM_6A, yang kesemuanya berupa batuan ubahan tersilisifikasi tersusun oleh kuarsa mengandung detritus butiran sangat halus dan serabut-serabut mineral ubahan dan amorf, dipotong urat-urat kuarsa sangat halus. Hasil pengukuran mikrotermometri masing-masing conto disajikan dalam Tabel 3. 


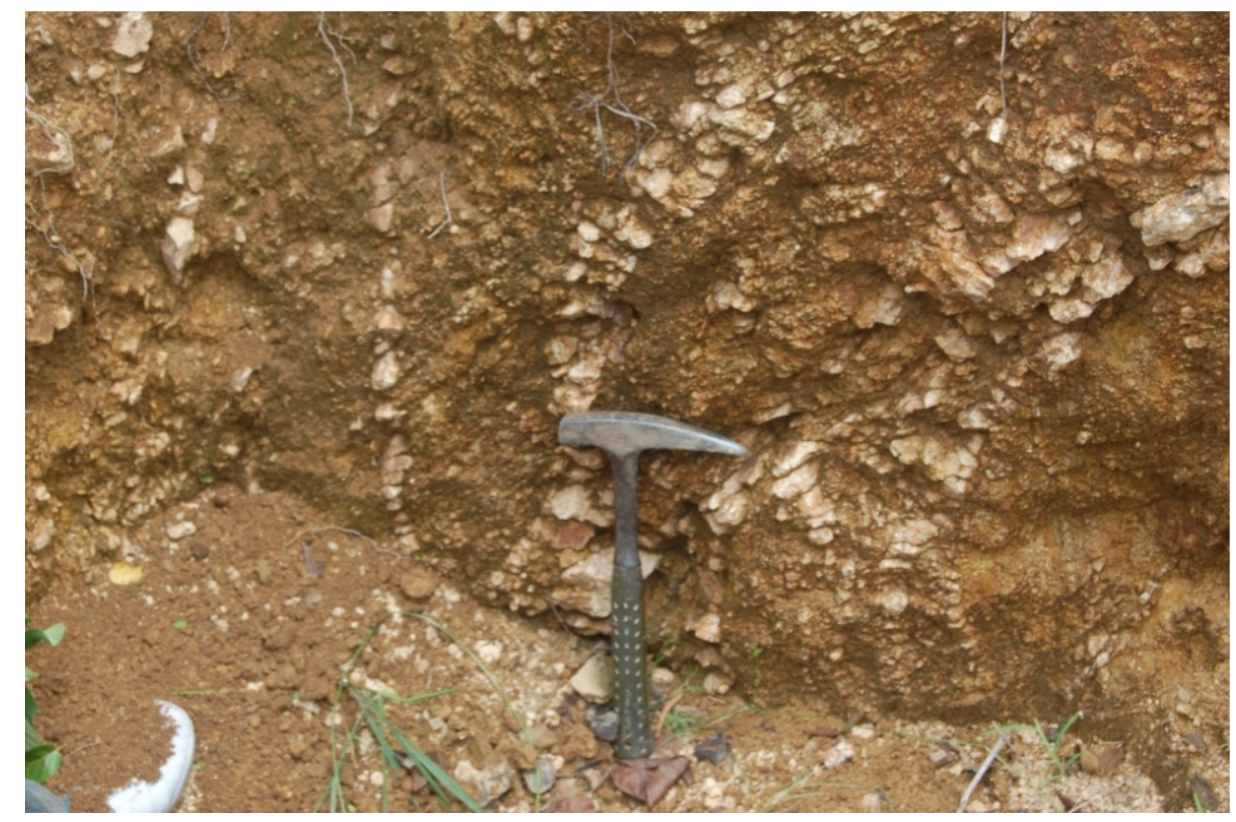

Gambar 5. Foto urat kuarsa memotong batuan syenodiorit pada sumur uji TPM 01

Tabel 2.

Hasil analisis kimia unsur (AAS)

\begin{tabular}{|c|c|c|c|c|c|c|c|c|c|}
\hline \multirow{2}{*}{ No. Conto } & \multicolumn{9}{|c|}{ Unsur } \\
\hline & $\mathrm{Cu}$ & $\mathbf{P b}$ & $\mathrm{Zn}$ & Ag & $\mathrm{Fe}$ & $\mathrm{Au}$ & As & Mo & $\mathrm{Sb}$ \\
\hline TPM 01A & 40 & 5526 & 379 & 3 & 2,98 & 0,017 & 5 & 2 & 7 \\
\hline TPM 01B & 20 & 2238 & 118 & 2 & 2,22 & 0,019 & 10 & 4 & 2 \\
\hline TPM 02A & 19 & 435 & 78 & 1 & 2,12 & 0,036 & 5 & $<2$ & 4 \\
\hline TPM 02B & 11 & 166 & 28 & 2 & 1,36 & 0,064 & 5 & $<2$ & $<2$ \\
\hline TPM 03A & 10 & 67 & 6 & 2 & 1,35 & 2,653 & $<2.5$ & 2 & 3 \\
\hline TPM 03B & 18 & 152 & 11 & $<0.5$ & 1,21 & 1,601 & 5 & 2 & 2 \\
\hline TPM 03C & 11 & 44 & 18 & 1 & 1,89 & 5,014 & 5 & 2 & $<2$ \\
\hline TPM 03D & 22 & 110 & 25 & 2 & 4,65 & 2,113 & 5 & 8 & $<2$ \\
\hline TPM 03E & 7 & 20 & 9 & $<0.5$ & 1,56 & 1,348 & $<2.5$ & 2 & 2 \\
\hline TPM 04A & 15 & 53 & 31 & $<0.5$ & 2,05 & 1,405 & $<2.5$ & 4 & $<2$ \\
\hline TPM 04B & 7 & 38 & 17 & $<0.5$ & 1,14 & 2,558 & $<2.5$ & 2 & $<2$ \\
\hline TPM 04C & 9 & 21 & 20 & $<0.5$ & 1,57 & 1,368 & $<2.5$ & 3 & 2 \\
\hline TPM 04D & 6 & 4 & 8 & $<0.5$ & 1,26 & 0,532 & $<2.5$ & 2 & 4 \\
\hline TPM 04E & 9 & 7 & 11 & $<0.5$ & 1,17 & 0,378 & $<2.5$ & 2 & $<2$ \\
\hline TPM 04F & 10 & 9 & 13 & $<0.5$ & 1,49 & 1,374 & $<2.5$ & 2 & $<2$ \\
\hline TPM 05A & 11 & 32 & 17 & $<0.5$ & 1,6 & 0,986 & 5 & 5 & $<2$ \\
\hline TPM 05B & 6 & 5 & 7 & $<0.5$ & 1,19 & 2,092 & 5 & $<2$ & $<2$ \\
\hline TPM 05C & 13 & 10 & 15 & $<0.5$ & 1,24 & 1,603 & $<2.5$ & $<2$ & 5 \\
\hline TPM 05D & 12 & 78 & 19 & $<0.5$ & 1,43 & 3,097 & 5 & 2 & $<2$ \\
\hline TPM 05E & 12 & 11 & 13 & 1 & 1,31 & 6,326 & 5 & 3 & $<2$ \\
\hline TPM 05F & 15 & 83 & 60 & 1 & 2,44 & 0,854 & 35 & 2 & 3 \\
\hline TPM 06A & 9 & 135 & 15 & $<0.5$ & 1,47 & 0,036 & 35 & 2 & 2 \\
\hline TPM 06B & 12 & 77 & 22 & $<0.5$ & 1,26 & 0,016 & 30 & 2 & $<2$ \\
\hline TPM 07 & 20 & 112 & 49 & 5 & 2,43 & 0,163 & 9 & 2 & 2 \\
\hline TPM 08 & 7 & 49 & 16 & $<0.5$ & 1,49 & 0,058 & 5 & $<2$ & $<2$ \\
\hline satuan unsu & dala & $p m$, & uali $F$ & dalam & & & & & \\
\hline
\end{tabular}




\section{MAKALAH ILMIAH}

Fotomikrografi menunjukkan adanya beberapa inklusi fluida dua fasa dan fase tunggal kaya air pada TPM_04A (Gambar 6), TPM_05D (Gambar 7) dan TPM_06A (Gambar 8).

\section{PEMBAHASAN}

Nilai unsur-unsur logam dasar $(\mathrm{Cu}, \mathrm{Pb}, \mathrm{Zn})$ paling besar terdapat pada sumur uji TPM01A, sementara nilai unsur Au paling tinggi pada TPM05. Hubungan antar unsur menunjukkan kaitan yang erat antara kadar

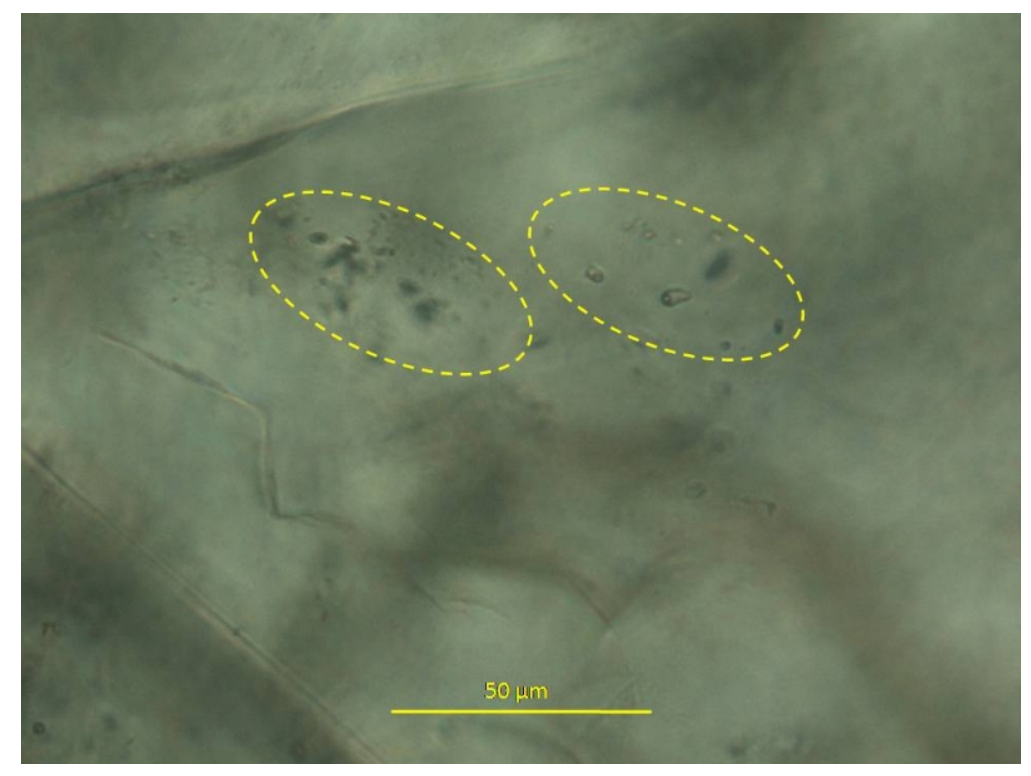

Gambar 6. Inkklusi fluida dua fasa (lingkaran kanan) dan fasa tunggal kaya air (lingkaran kiri) TPM_04A

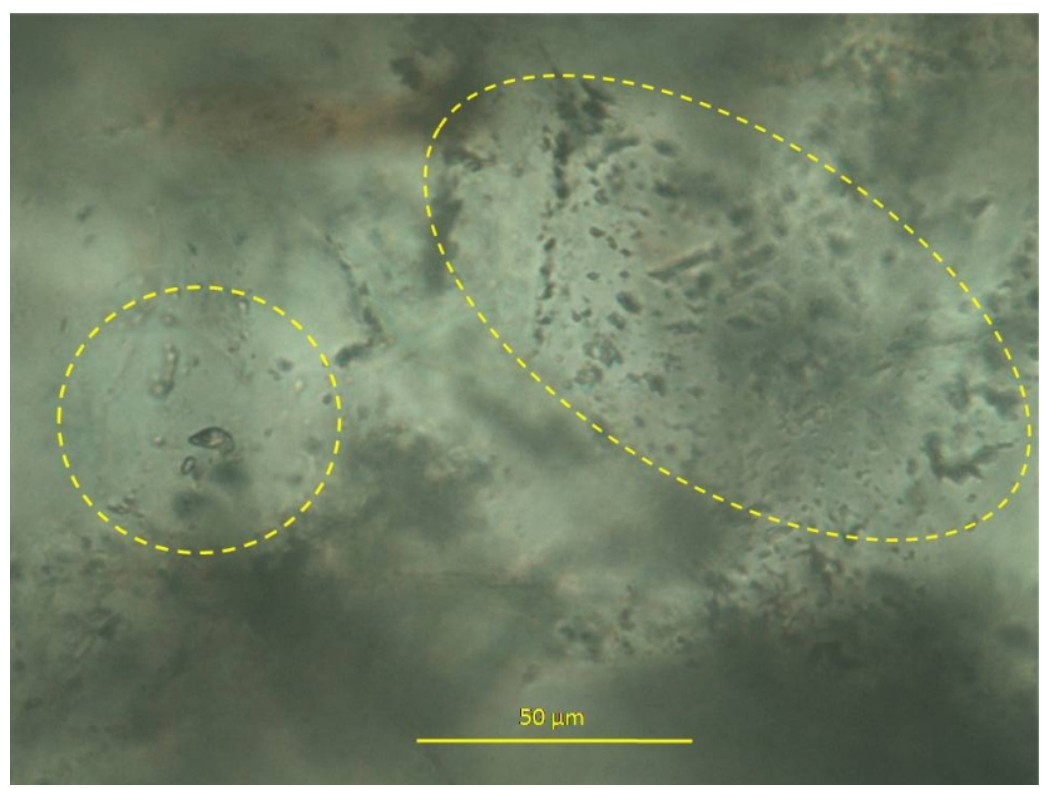

Gambar 7. Inklusi fluida sebagian besar fasa tunggal air, dibagian kanan didominasi fasa tunggal kaya air dan umumnya berbentuk necking, dibagian tengah kiri terlihat beberapa inklusi fasa ganda yang dapat diukur. 


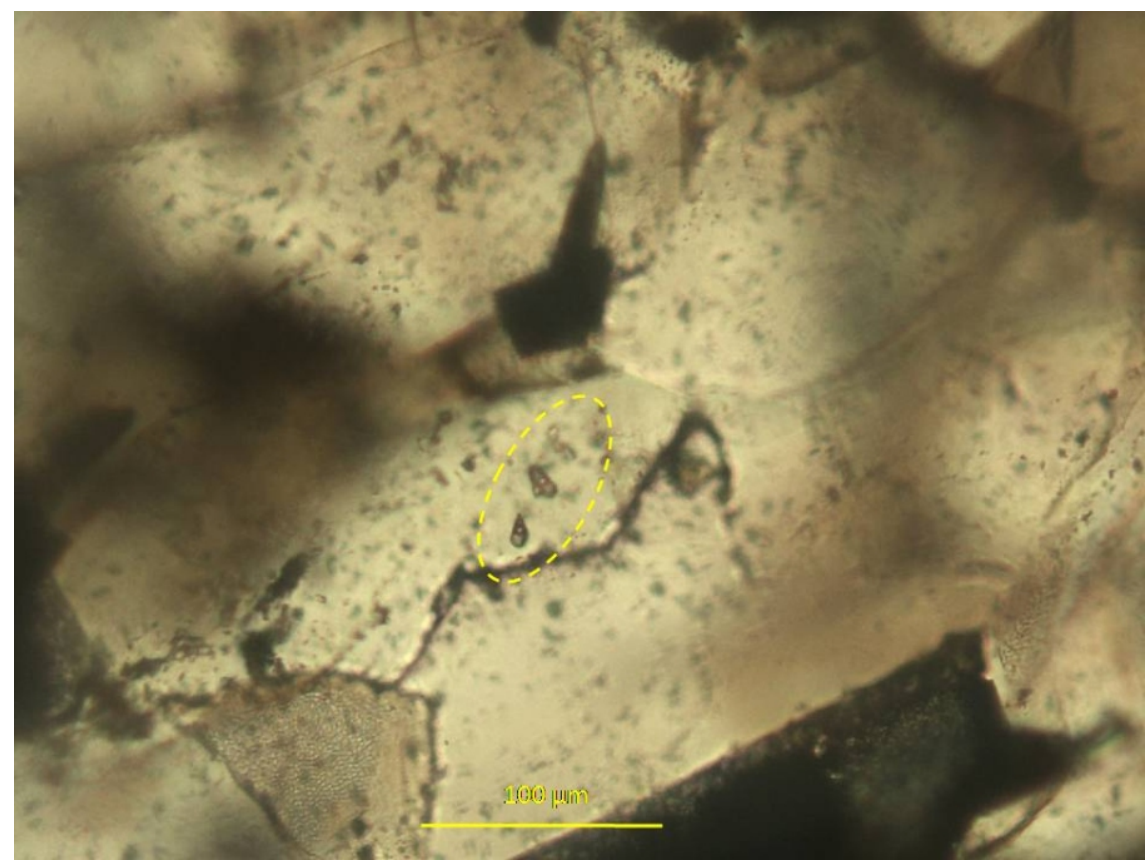

Gambar 8. Inklusi fluida fasa ganda subhedral didalam kristal prismatik kasar kuarsa tipe urat TPM_06A.

Tabel 4.

Hubungan antar unsur

\begin{tabular}{|lrrrrrrrrrr}
\hline Unsur & \multicolumn{1}{c}{$\mathrm{Cu}$} & $\mathrm{Pb}$ & $\mathrm{Zn}$ & $\mathrm{Ag}$ & $\mathrm{Fe}$ & $\mathrm{Au}$ & $\mathrm{As}$ & $\mathrm{Mo}$ & $\mathrm{Sb}$ \\
\hline $\mathrm{Cu}$ & 1 & & & & & & & & \\
$\mathrm{~Pb}$ & $\mathbf{0 . 8 2}$ & 1 & & & & & & & \\
$\mathrm{Zn}$ & $\mathbf{0 . 8 7}$ & $\mathbf{0 . 9 8}$ & 1 & & & & & & \\
$\mathrm{Ag}$ & $\mathbf{0 . 6 1}$ & 0.43 & 0.47 & 1 & & & & & \\
$\mathrm{Fe}$ & $\mathbf{0 . 6 8}$ & 0.38 & 0.44 & $\mathbf{0 . 5 2}$ & 1 & & & & \\
$\mathrm{Au}$ & -0.21 & -0.27 & -0.29 & -0.18 & -0.10 & 1 & & & \\
$\mathrm{As}$ & 0.02 & -0.03 & 0.02 & -0.02 & 0.07 & -0.29 & 1 & & \\
$\mathrm{Mo}$ & 0.24 & -0.01 & -0.03 & 0.10 & $\mathbf{0 . 6 9}$ & 0.09 & -0.12 & 1 & \\
$\mathrm{Sb}$ & $\mathbf{0 . 6 0}$ & $\mathbf{0 . 6 8}$ & $\mathbf{0 . 7 3}$ & 0.23 & 0.20 & -0.22 & -0.09 & -0.21 & 1 \\
\hline
\end{tabular}

$\mathrm{Cu}, \mathrm{Pb}, \mathrm{Zn}$ dengan nilai koefisien korelasi diatas 0,8. Sementara kadar unsur Au tidak memiliki hubungan dengan kadar unsur lain, bahkan menunjukkan nilai hubungan yang negatif (Tabel 4).

Analisis inklusi fluida menunjukkan pembentukan mineralisasi masih berada di kisaran suhu $220^{\circ} \mathrm{C}-300^{\circ} \mathrm{C}$. Kisaran temperatur ini masih merupakan kisaran yang wajar untuk pembentukan mineralisasi di lingkungan epitermal. Namun dari sisi lain nilai salinitasnya memiliki nilai agak tinggi dibanding dengan kebanyakan endapan epitermal di tempat lain, seperti di Cineam, Tasikmalaya (Nugroho Widhi,1998) yang mempunyai temperatur pembentukan 
mineralisasi berada pada kisaran $200^{\circ} \mathrm{C}$ $300^{\circ} \mathrm{C}$ tetapi salinitas berada dibawah 1,5 $w t \% \mathrm{NaCl}$.

Hubungan antara mineralisasi emas beserta mineral penunjuk (pathfinder) dengan temperatur dijelaskan sebagai berikut: TPM_04A memiliki temperatur 220$250^{\circ} \mathrm{C}$, salinitas $3.5-3.7 \mathrm{wt} \% \mathrm{NaCl}$ dengan kadar 1,405 ppm Au, <2,5 ppm As, Mo dan $\mathrm{Sb}$ relatif kecil. TPM_05D, temperatur 220$250^{\circ} \mathrm{C}$ salinitas $2,5-2,9 \mathrm{wt} \% \mathrm{NaCl}$ dengan 3,097 ppm Au, 5 ppm As, 3 ppm Mo dan $\mathrm{Sb}<$ $2 \mathrm{ppm}$. Sedangkan pada TPM_06A dengan temperatur $230-300^{\circ} \mathrm{C}$, salinitas $1,4-1,8 \mathrm{wt} \%$ $\mathrm{NaCl}$ memiliki 0,03 ppm Au, 35 ppm As, 2 ppm Mo dan 2 ppm Sb. Melihat pola tersebut dapat ditarik gambaran saat temperatur tinggi nilai $\mathrm{Au}$ menurun dan As meningkat (TPM_05D dan TPM_06A).

Sementara itu kadar logam dasar $(\mathrm{Cu}$, $\mathrm{Pb}, \mathrm{Zn}$ ) ditunjukkan dari conto TPM_04A dengan kadar yang tinggi pada temperatur mineralisasi antara $200^{\circ} \mathrm{C}-300^{\circ} \mathrm{C}$, salinitas yang paling tinggi $(3,3-3,7 \mathrm{Wt} . \% \mathrm{NaCl})$ dibanding dengan conto lain

TPM_06 menunjukkan temperatur paling tinggi diantara conto lain, namun memiliki salinitas paling rendah. Sementara dalam kondisi yang umum temperatur yang meningkat hampir selalu diikuti dengan meningkatnya nilai salinitas dan kedalaman. Hal ini kemungkinan dipengaruhi oleh faktor pengambilan conto yang berada pada lokasi paling jauh. Kemungkinan lainnya disebabkan oleh adanya perbedaan komposisi larutan hidrotermal dan/atau batuan samping. Jika dilihat dari kedalaman pembentukan mineralisasi antara TPM_04A, TPM_05D dengan TPM_06A terdapat perbedaan yang cukup mencolok. TPM_04A memiliki kisaran kedalaman $291, \overline{53} \mathrm{~m}$, TPM_05D pada kedalaman 350,85 m dan TPM.06A dari 434,30-863,16 $\mathrm{m}$. Hal tersebut menunjukkan pembentukan mineralisasi antara TPM_06A dengan TPM_04A dan TPM_05D telah mengalami pergeseran dikarenakan perbedaan kedalaman. (Gambar 9).

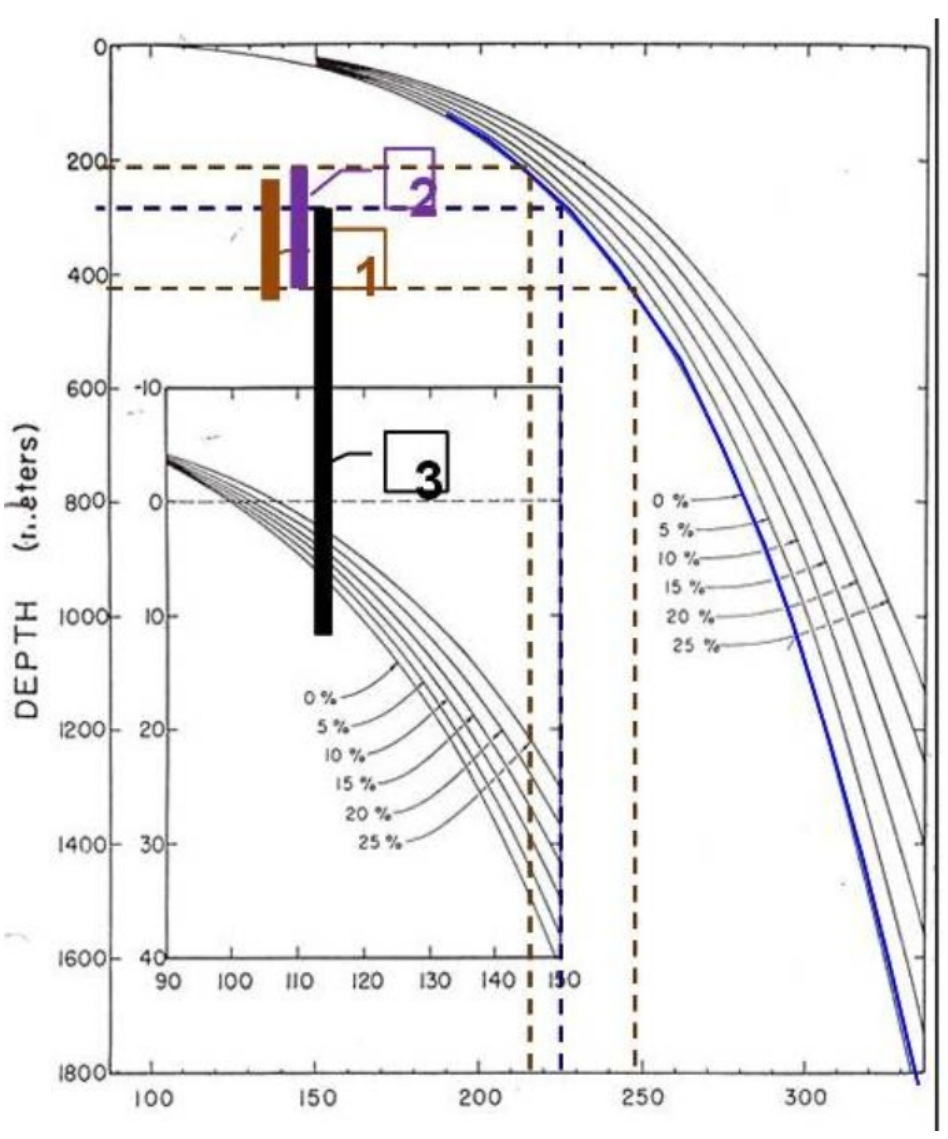

1) TPM_04A, 2) TPM05D, 3) TPM_06A.

Gambar 9. Diagram menunjukkan kisaran kedālaman pembentukan mineralisasi di daerah penyelidikan (Hass, 1971) 


\section{KESIMPULAN}

Mineralisasi emas di daerah Satoko terjadi pada batuan induk syenodiorit yang telah mengalami ubahan intensif argilik, berupa urat-urat tipis kuarsa yang membentuk zona dengan lebar mencapai 40 $\mathrm{cm}$. Mineralisasi terjadi pada suhu berkisar antara $220-300^{\circ} \mathrm{C}$ dan kedalaman antara 291, 53-863,16 m.

Kadar kandungan $\mathrm{Cu}, \mathrm{Pb}$ dan $\mathrm{Zn}$ menunjukkan hubungan yang erat dengan nilai koefisien korelasi diatas 0,8 , sementara kadar unsur $\mathrm{Au}$ tidak memiliki hubungan dengan kadar unsur lain, bahkan menunjukkan nilai hubungan yang negatif
Kecenderungan perbedaan suhu dan salinitas dari conto yang diambil berjauhan kemungkinan disebabkan oleh perbedaan komposisi larutan hidrothermal ataupun batuan samping.

\section{UCAPAN TERIMAKASIH}

Terimakasih yang sebesar-besarnya penulis sampaikan kepada rekan-rekan tim Prospeksi Mineral Logam di Kabupaten Polewali Mandar yang telah membantu pelaksanaan kegiatan lapangan dan kepada Ir. Danny Z Herman M.Sc atas diskusi sehingga terbitnya makalah ini.

\section{DAFTAR PUSTAKA}

Anonim, 2001, Laporan Pelepasan Keseluruhan, PT. North Mining Toraja (Tidak dipublikasikan).

Djuri, Sudjatmiko, Bachri S \& Sukido, 1998, Peta Geologi Lembar Majene dan bagian Barat Lembar Palopo, Sulawesi, Edisi kedua dalam skala 1 : 250.000, Pusat Survey Geologi

Hass,J.L., 1971. The effects of salinity on the maximum thermal gradient of a hydrothermal system at hydrostatic pressure. Economic Geology, 66 h. 940-946.

Nugroho Widhi B, 1998, Epithermal gold mineralization in the Cineam Area, Thesis, Hokaido University, Japan.

Priadi,B., H. Bellon, R.C. Maury, M. Polve, R. Soeriaatmadja \& J.C. Philippet, 1994. Magmatic evolution in Sulawesi in the light of new 40K-40Ar age data. Proceedings 23rd Annual Converence IAGI, Jakarta, p.355-369.

Van Leeuwen,T.M dan Pieters,P.E, 2011. Mineral Deposits of Sulawesi. Proceedings of The Sulawesi Mineral Resources, MGEI, p. 1-130. 